The report as a whole deals with the situation as it existed at the outbreak of war ; and it cannot be expected that much further progress will be made within the next year or two. At the same time, as is pointed out in an introductory footnote, the War has brought many of the potential advantages of electricity into even sharper relief. From a shortage of cod liver oil comes a new interest in ultra-violet irradiation; the more frequent use of female labour makes ease of control an important consideration; scarcity of imported feeding stuffs encourages a return to the earlier practice of grinding and preparing foodstuffs on the farm; and so on. But, in his final summary, the author of the report takes the longer view and looks forward to the time, twentyfive or forty years hence, when on all but a small proportion of unreachable farms electricity is used as a matter of course, for all stationary power and for all heating operations. This state of affairs is very likely to come about-not, perhaps, as the direct result of technical or agricultural research, but as a matter of sociological progress. The future of agriculture in Great Britain is bound to depend a great deal on giving the rural dweller his due share of urban amenities, and in America it is recognized already that the seller of electric kettles, cookers and washing machines plays a great part in the spread of farm electrification.

\title{
FORESTRY IN AFRICA
}

$\mathrm{I}^{\mathrm{T}}$ is interesting to note in recent annual forestry reports how what may be termed a correct and long-sighted forest policy is gradually becoming recognized by the civil administration as a matter which can no longer be left to chance. This has recently been exemplified in Nature. In the Gold Coast annual report (1938-39, Govt. Printer, Accra, 1939) the Conservator, in discussing the history of the forests, says that though some thirty-one years ago the indirect value of the maintenance of a proportion of tropical lands under forest was clearly stressed, yet the progress of reserving forests for the use of future generations, the maintenance of soil fertility, and so forth, has not proved an easy task. Forests, of necessity, occupy land, he says; and difficulties are increased when all the land, although surplus to immediate wants, is owned by a community with an unawakened national sense; to the indivividuals the cash resulting from an immediate sale is much to be preferred to the somewhat abstruse prospects from reservation in favour of future generations or a possible improvement in their water supplies. The failure to press for a more rapid selection of forests for reserves when surplus land was plentiful has resulted in an increasing opposition which education and propaganda are only gradually lessening; while the remaining forests of the Colony can no longer be regarded as excessive if the happiness and health of the community are to be assured.

In the Nigerian forestry report for 1939 (Govt. Printer, Lagos, 1940) the Conservator re-defines the aims of forestry in that part of West Africa on the well-known lines which have been so often in the past disregarded by the Governments. He sounds a wise note, too often neglected, that the productive motive, though secondary (it has usually been placed first), is an important one. "If," he says, "forest, shelterbelts and shade trees have to be maintained for protection, it is clear that the fullest possible use should be made of them, and this can best be effected by fostering African industries using forest produce as raw material." These industries, as was foreseen several years ago by senior French district administrative officers in the Ivory Coast, will in the future be more important in the economy of the country than any export trade in timber overseas. It is a step in advance that the head of a West African Forest Department should at length express this important view. The Conservator remarks that the Department is becoming continually more involved, with other rural departments, in the study of the wider problems of land use and land planning. But here again new forest reservation, so urgently needed, proceeds slowly in the south owing to political and legal difficulties and problems of land tenure; and this in spite of the fact that all the forms of deterioration - of soil, climate and water supply -are in active progress in various parts of the southern provinces. There can be little hope of more than local remedy until the chaotic situation as regards land tenure is resolutely tackled.

The annual forestry report for Kenya for 1939 (Govt. Printer, Nairobi, 1940) strikes rather a different note. The outbreak of war has caused some reduction of the staff (junior officers allowed to join or called up to join the Army, which has been the case in both Nigeria and the Gold Coast), but has considerably increased the demand for forest produce. This latter and the increased revenue thereby realized might have proved of some satisfaction to the Department-especially the revival in the old export trade of boritis (mangrove) poles-were it not for the former factor. The demand for produce from the forests was increased during the latter part of the year by War Department demands. At all sawmills trade was fairly brisk, and several millers increased their output considerably by improved organization and efficiency. Unfortunately the urgent military demand for building timber has meant that air-seasoning has not been possible prior to the delivery of the timber.

Regrettable as this may seem, equally unfortunate is the fact that most of the timber requisitioned by the military authorities in war-time is utilized for purposes often ephemeral and in any event has a comparatively short life. A far more important point is the factor that, with a reduced staff, who is to undertake the necessary supervision over the extra fellings which are to take place ? The limit to further indiscriminate fellings and resultant ultimate dis appearance of the African forests has been reached, or is perilously close. If war fellings are to take place unchecked in forests the volume content of which is but imperfectly known, neither administration nor the local forest department is fulfilling its true functions to the native communities. 